$$
\text { "csernoch" — 2009/5/29 — 9:48 — page } 119 \text { — \#1 }
$$

\title{
Teaching word processing - the theory behind
}

\author{
MÁRIa Csernoch
}

Abstract. It is widely thought and believed that word processors - especially MS Wordare software, which everyone can use. However, if we take a closer look at the documents we find that the picture is not at all that clear. In most of these documents even the basic rules of word processing are broken. The question is how it is possible that most of the users are satisfied with their performance, and do not realize that they only use a less noisy typewriter, and not able to take advantage of the opportunities offered by these software. In the search of clearing this misunderstanding I found that there are no publicly available sources, which would clearly set the rules to determine when the documents are properly formatted. Here I set three maxims which, together, are able to control the tools applied in word processing in order to create properly formatted texts. In summary, they state that the layout of a properly formatted text should be invariant to modification, that is, any modification of the body of text should not initiate its re-formatting. To prove that these maxims work and to show that we desperately need them I give examples of works of professionals from the administration, of those who passed ECDL exams, of teachers of various subjects, and finally of teachers of Informatics.

Key words and phrases: word processing, properly formatted text, typical mistakes.

ZDM Subject Classification: U10.

\section{Introduction}

Twenty-five years ago we were dreaming of times when everyone has access to computers, not only those who work for a living in the computer business. The time has come with all its blessings and plagues, computers have reached everyone from the youngest generations to the aged. It seems that without computers life

Copyright (C) 2009 by University of Debrecen 


$$
\text { "csernoch" — 2009/5/29 — 9:48 — page } 120 \text { — \#2 }
$$

is "unbearable" any more. In this "heavenly condition" I happen to teach some basic applications to high school and university students. Being involved in two levels of education I have the chance to follow the progress of students from high school to university. Besides my experience in school it is unavoidable to come across the computer aided works of adults.

Using computers covers such a wide range of experience that in this study I mean to focus only on one aspect. I ventured to test the word processing ability of users. To pick this special field I have several reasons. Among them the number of users has the highest priority. Almost everyone who has access to a computer uses word processors. The classes leaving school in the last ten to fifteen years have had the chance to study word processing in school, and adults, who left school earlier have also had several opportunities to study word processing in organized forms. This means that among the users of word processors the number of those who studied word processing within the education system has increased substantially.

In this study I present examples which clearly show that teaching word processing is not effective enough. In general, teachers are not able to reach the state when students leaving schools - either young or adult - are able to work on their own, and provide properly formatted texts. I found that one of the reasons for this underachievement is that no theoretical background is established for this science and without proper guidelines neither the teacher nor the students are able to achieve their best. To overcome this problem I provide three general rules - maxims - which together seem satisfactory enough for students to avoid basic mistakes.

\section{Methods}

\subsection{What is missing?}

Studying something on a higher level usually means to facilitate the students with some theoretical background and to give opportunities to practice enough to be able to work on their own after leaving school. However, at present I cannot see either the properly given theoretical guidelines or the opportunities to practice enough at least to earn basic knowledge of word processing. In this study I present several examples of incorrectly edited texts to show how "professionals" - who passed ECDL exams, and who do word processing for a living - use MS Word, focusing on the typical mistakes which occur frequently in their texts. 


$$
\text { "csernoch" — 2009/5/29 — 9:48 — page } 121 \text { — \#3 }
$$

Before dealing with these obvious technical mistakes carried out by users who should not be so ignorant we have to find reasons for their foreseen underachievement. The problem, of course, is complicated, and several reasons can be found. What is obvious, however, that without general rules there is no hope to establish a science, a subject.

\subsection{Word processors and "properly formatted" texts}

To see whether a text is properly formatted or not, first the definition of the "properly formatted" text should be given. I have searched through several available books, leaflets, web pages but was not able to find an exact definition of the "properly formatted" text. Instead I have found

- the definition of word processor and a list of services which a word processor should offer,

- the basic features of a text which is created with a word processor, and finally

- the comparison of typewriters and word processors.

None of the articles contain the definition which I was looking for, but the three approaches share common features, which might lead us closer to the solution of the problem. All of the approaches emphasize that one of the great advantages of a word processor is that we can move freely in the current text, and as a result the text can be modified.

Many of the found "definitions" give a list of basic functions of the word processors:

- typing [1],[2]

- saving documents [1], [4]

- opening documents [1], [4]

- copying [1], [5]

- pasting [1], [5]

- cutting [1], [5]

- printing [1], [4], [5]

- checking spelling [1] [3]

Many of the found "definitions" give reasons why it is worth using a word processor:

- we can modify the text without re-typing [3], [4], [5]

- we can set and modify the size of the paper and the margins [3], [4], [5] 
- search options are available [3], [5]

- automated line break with carriage return is included [2], [5].

The comparison of word processors to typewriters is also common in the introductory section of teaching materials. I strongly disagree with such a comparison for at least two reasons. First of all, old bad habits inherited from the typewriters' era cause the most serious mistakes in word processing: using ENTER at the end of the lines and between paragraphs, and the endless usage of SPACES and TABS. The other reason is that the new generation never met these old-fashioned typewriters, and luckily they cannot compare the word processors to them. Sentences like the following should be omitted:

- "As we got used to in creating texts with typewriters..." [2]

- "Word processors mean in the world of computers the typewriters..." [3] or

- "The great advantage of word processing over using a typewriter..." [5], [22].

Apart from these statements in several documents, either printed or electronic, one finds that with word processors "one can create nice, aesthetic documents easily and fast" ${ }^{1}$ [4]. Of course, if someone knows how to use these pieces of software the work is fast, but still there is no guarantee for a typographically correct and aesthetic document. The question is how fast and properly those can work who cannot use a word processor? I do not think that they find the work easy and fast. Just take a closer look at Figure 2-5. Creating these documents could be quite tiresome and boring and even more challenging if any modification was applied to them.

I do not find some of the documents aesthetic either. Just take a look at those texts, which ended up on the margins (Figure 2), those where the layout of the pictures are set incorrectly (Figure 2, 4 and 5), and where all the formats were lost just because the user was not able to create a Word document from a text file (Figure 8).

I think one of the greatest mistakes in connection with word processors is to create the false image that these programs are toys and everyone can use them properly without any preparation. These misleading statements result in false judgment of word processing abilities (Figure 1).

1 ... könnyen, gyorsan szép, esztétikus kiadványokat tudsz készÍteni. (translated to English by Author) 


$$
\text { "csernoch" — 2009/5/29 — 9:48 — page } 123 \text { — \#5 }
$$
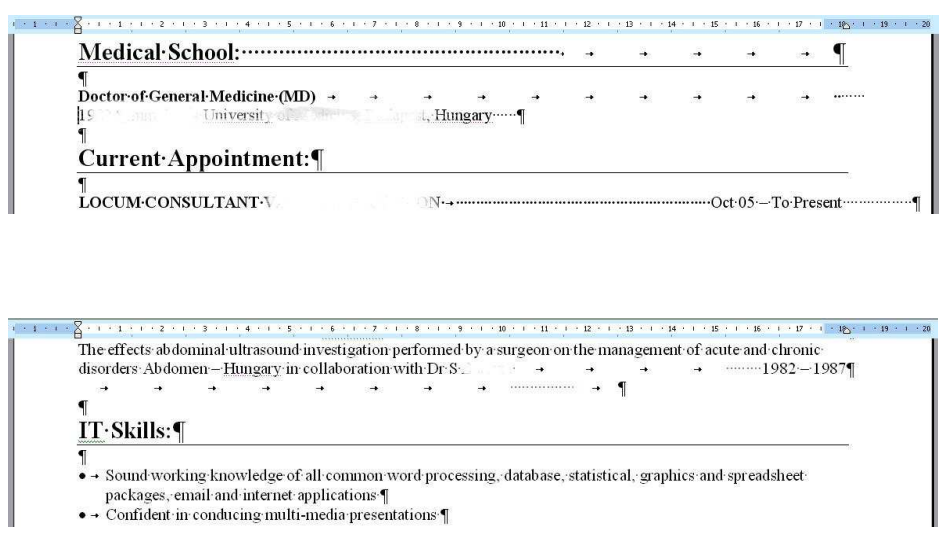

Figure 1. The writer of this curriculum vitae states that (s)he has a "Sound working knowledge of all common word processing...". The example shows that not all but even this word processor caused him serious problems.

\section{3. "Properly formatted" text}

The example in Figure 1 clearly shows that its writer has no clear knowledge of what a "properly formatted" text is and this might have led to his false judgment of his word processing ability. Most of the examples given later in this study are from users who were satisfied with their word processing ability and had no idea that the tools they used were inadequate.

I think, therefore that first of all a correct definition is needed, because as the given quasi "definitions" show they all miss the essence of the definition of the "properly formatted" text.

\section{The maxims of the properly formatted text}

The simplest definition of a properly formatted text, if using a word processor, can be summarized as follows. The layout of the text should be invariant to modification(s). In other words, any modification of the body of the text should not initiate its re-formatting. This simple requirement can be expanded to three maxims. 


$$
\text { "csernoch" — 2009/5/29 — 9:48 — page } 124 \text { — \#6 }
$$

Mária Csernoch

\subsection{First maxim: allow intended editing of the text}

The first maxim - following previous "definitions" - states that one should be allowed to edit a text generated by a word processor. This means that one can intentionally add, delete, move, and copy text slices in or into an already existing document.

The first maxim, however, is clearly not enough to reach a properly formatted document, because it would allow additional unintended editing of the text. In this context unintentional editing means typing and/or deleting which was not planned by the user. There are a number of examples where unintentional editing would be required following the modification of the text.

- If one "centralized" the title of the document with SPACES and/or TABS, and then deleted or added characters to this title one would also have to add or delete Spaces/TABS also to "centralize" the title again [20], [21].

- Similarly, if one used manual hyphenation and then edited the text, the DASH and the ENTER characters would also have to be deleted and new ones would have to be inserted [20].

- Even more tiresome if one ended every single line with an ENTER and later on had to change the margin or the font type or size. One would have to delete most of the ENTERS and insert new ones [20].

\subsection{Second maxim: exclude unintended editing}

The second maxim should thus exclude such extra editing of the text. That is, beyond the intention of the user there should be no need for further editing of the text. This second maxim will - beyond those mentioned above - rule out

- manual paragraph numbering,

- manual page numbering,

- manual footnotes,

- headers, footers on the text area [18], [19].

\subsection{Third maxim: exclude incorrect formats}

The third maxim is to handle the applied, but incorrect formats. That is, after editing the text it should still keep its intentional format(s). This maxim will rule out the following incorrect formats. 


$$
\text { "csernoch" — 2009/5/29 — 9:48 — page } 125 \text { — \#7 }
$$

- If the text slice is centralized by indents is incorrect, because if one used left indent to centralize a title and then modified the text one would have to move the left indent again to keep the title in position.

- The same is true for tab stops. To use left aligned tab stops for the right or decimal alignment of whole numbers is incorrect, and should be avoided. This incorrect method requires the intensive use of SPACES to imitate the correct place value of each digit.

- If one had different left align tab stops for each line of a table to centralize that column and then the text is modified in one of the lines the incorrect tab stops would have to be modified in that line also to keep the image of centralization, because it was only an image, not a real centralization.

- Using newspaper columns instead of parallel columns. Parallel columns cannot be substituted by newspaper columns, since their reading order is different. Word does not support parallel columns directly, but it can be mimicked by a table which contains as many table rows as required by the number of the logically compact units of the text [19].

\subsection{Beyond the boundaries of the three maxims}

None of the maxims will rule out, however, the modification of the positions of tab stops, if the text after the modification in the column(s) turns out to be somewhat longer than it was originally planned. Since, the conversion of tab stops to table is a correct solution if the modified text turns out to be so long that it cannot fit into the tabbed columns [19] this case should not be considered as mistake.

Furthermore, these maxims do not set rules for a typographically, syntactically, and semantically correct document, they are only to control the word processing techniques applied to a text. We have to keep in mind, however, that to create an aesthetic document not only the word processing techniques but the above mentioned criteria must be kept. Noteworthy is that for these already accepted rules exist.

\section{Works of "professionals"}

In this chapter I collect examples of various "word processing techniques", which should be avoided, because they broke the above maxims. These are not 


$$
\text { "csernoch" — 2009/5/29 — 9:48 — page } 126 \text { - \#8 }
$$

real word processing techniques, because in several cases the SPACE and the ENTER characters are used exclusively (Figure 2). In other examples the selected formatting is incorrect, not suitable to carry out the given task, and again the ENTER and SPACE characters, and in addition, the default TAB characters are chosen to correct the mistakes (Figure 2(f), 4(b) and 5). In other cases another incorrect solution is chosen to correct the mistake (Figure 4(a), 8(d)).

One would say that finding such examples is not a big challenge since, unfortunately, the Internet is loaded with texts carrying these typical mistakes. The reason why these examples are presented here is that they are from professionals, whose job is to create texts, and who are supposed to provide examples of correctly formatted texts.

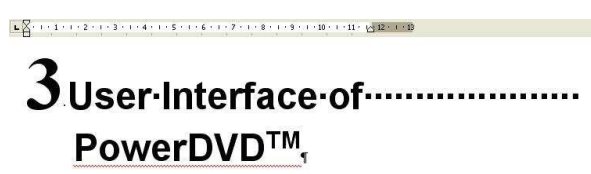

(a)

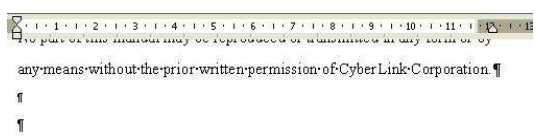

(c)

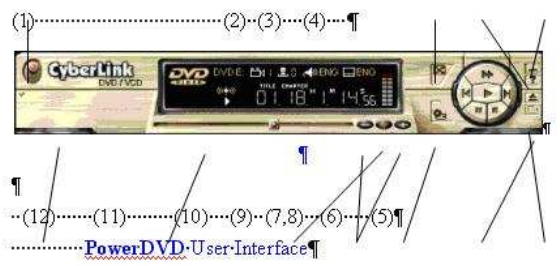

(e)

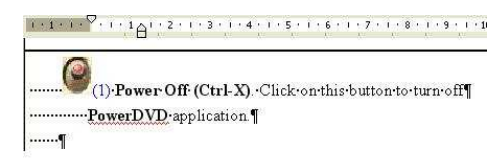

(b)

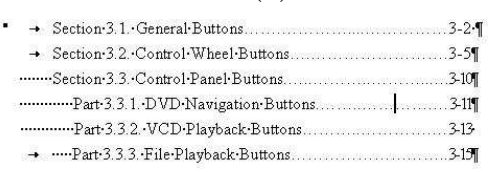

(d)

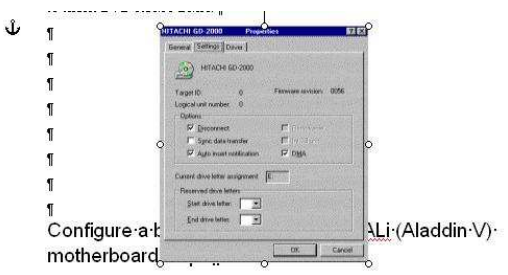

(f)

Figure 2. Examples of mistakes found in one of the User Manual of Cyberlink. In this text everything went wrong, all of the maxims given above are broken. Even the traces of any correct word processing are missing from this text. 


$$
\text { "csernoch" — 2009/5/29 — 9:48 — page } 127 \text { — \#9 }
$$

\subsection{User Manual from CyberLink}

The first examples (Figure 2) are from a User Manual ${ }^{2}$, which is expected to be correctly word processed, because it is from a software company. In a paradox way, this company sells its software expecting the users to use it correctly, while they use someone else's software and do not feel that they should learn to use it properly.

In Figure 2(a)-2(c) the different color of the rulers clearly indicates that the margins are used to enter characters. These characters are mainly SpACES, but in Figure 2(c) the negative indentation of the paragraph allows the user to enter text on the margin area, too (for similar example see also Figure 1).

In Figure 2 we can find examples for another function of SPACES, substituting the correct formatting command with them:

- in 2(a) Spaces are used to reach the next line (for similar example see also Figure 1),

- in 2(b) they substitute indentation,

- in 2(d) they substitute positioned tab stops (for similar example see also Figure 1) or indentations,

- in 2(e) they substitute positioned tabs for the numbers and substitute center alignment in the last line of the picture.

We can find examples of incorrect usage of ENTERS also.

Unfortunately, marking the end of paragraphs - which is vital in working with MS Word-, the role of the end-of-paragraph mark seems confusing in the works of many users. In Figure 2(b) an end-of-paragraph character is inserted into the sentence, while in Figure 2(d) an end-of-paragraph character is missing from the last but one line (for similar example see also Figure 1).

ENTERS are used to leave space between paragraphs (for similar example see also Figure 1) and to reach the next page also. In Figure 2(b), 2(c) and 2(f) unnecessary ENTERs are inserted into the texts. In Figure 2(f) the layout of the picture is set incorrectly, so ENTERS are used to leave space. Here, the layout of the picture should have been set to "In line with text" to avoid the ENTERS and the overlapping with the following text.

Besides the SPACE and ENTER characters the Dot character and numbers are also common in substituting formatting. In Figure 2(d) the position of the cursor indicates that no leader characters are set, instead the Dot character is inserted

${ }^{2}$ CyberLink PowerDVD ${ }^{\mathrm{TM}}$

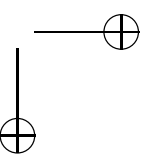


several times. In Figure 2(a) there is manual, instead of automatic paragraph numbering.

\subsubsection{Documents from the Ministry of Education}

The above listed examples are not unique. Unfortunately, several other official documents can be found with the same or similar mistakes. The mistakes listed in this chapter are from the Ministry of Education. Texts from the Ministry of Education are one of the most devastating because the end-users of these texts are students in schools. With these incorrectly formatted texts the students are given bad examples and easily feel the right to follow them.

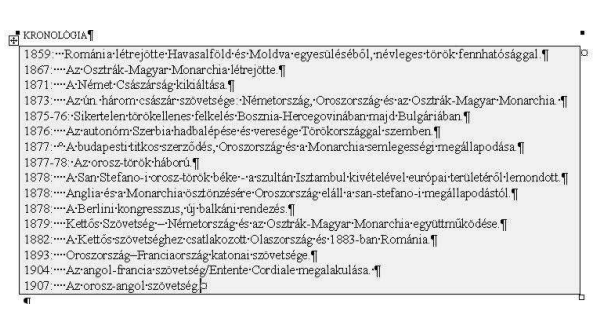

(a)

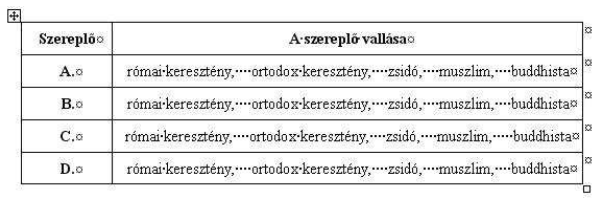

(c)

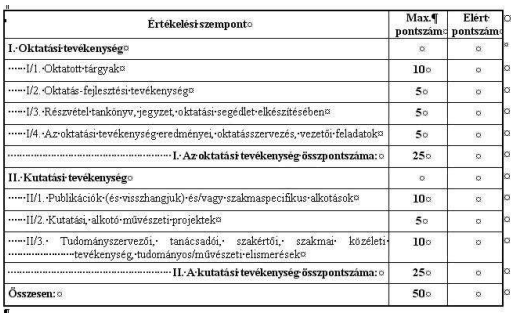

(b)

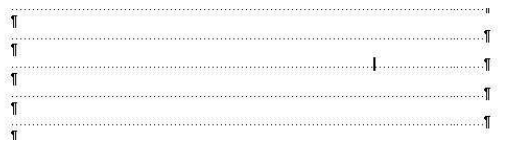

(d)

Figure 3. Examples from issues presented by the Ministry of Education. The examples very well demonstrate the intensive usage of the SPACE character.

SPACE characters are used for substituting positioned tab stops (Figure 3(a) and $3(\mathrm{c})$ ), indents (Figure 3(b)), and right alignment (Figure 3(b)). Dots are used to fill in the lines in Figure 3(d), instead of using positioned tab stop with a leader character. In this same document I found 174 such lines - just multiply the number of Dots with the number of lines -, after this it is no wonder that in some opinion word processing is a "boring task".

In Figures 4(a) and 4(b) commonly encountered mistakes are presented. To decide on the layout of the pictures causes problems. In Figure 4(b) the mistake 


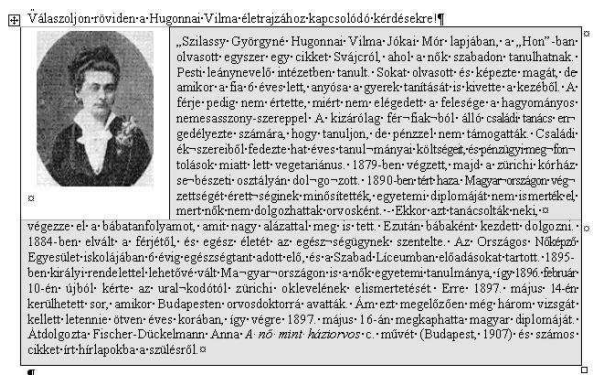

(a)

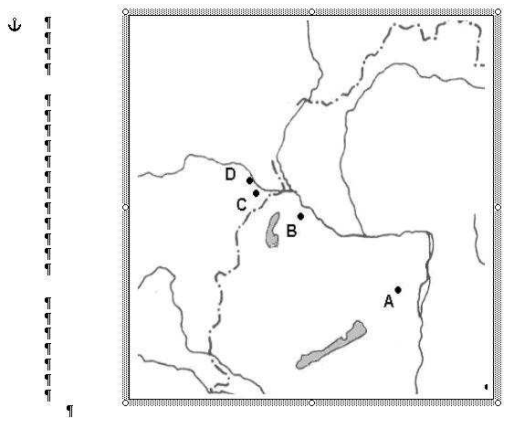

(b)

Figure 4. Examples from documents presented by the Ministry of Education. Pictures also proved to be a hard nut to crack.

of Figure 2(f) is repeated. Again, the layout of the picture was set to "Square" instead of "In line with text". In contrast, in Figure 4(a) the "solution" is the opposite, the layout should have been set to "Square", instead, it was set to "In line with text". In Figure 4(a), the user in the first row of the table used two cells, one for the picture and one for the text parallel with the picture, and then inserted a new table row "to wrap the picture".

\subsubsection{Educational documents}

Two more examples are listed in this chapter in connection with education. The authors of these documents are teachers. Similarly, to documents from the Ministry of Education, the end-users of these documents are students, and they should not have been supplied with documents in such condition. It is already distressing that documents from the administration carry numerous mistakes, but the following examples demonstrate that practicing teachers, who are in close contact with students, also do not have a clear idea about basic word processing solutions.

For Figure 5(a), I selected two examples from the same text. These examples represent the word processing style of the author very well. Default tab positions, TAB characters and SPACES are used to align text, and the DOT character to fill in the line, numbering is manual, "Expanded Character Spaces" is imitated with SPACE characters, the layout of the picture is "In line with text", instead of 


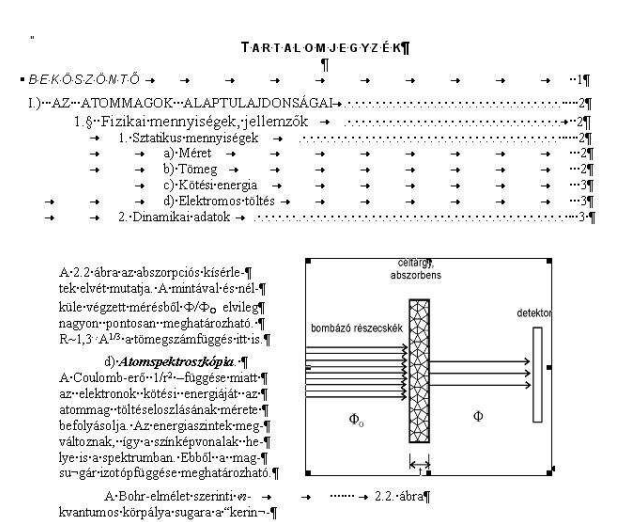

(a)

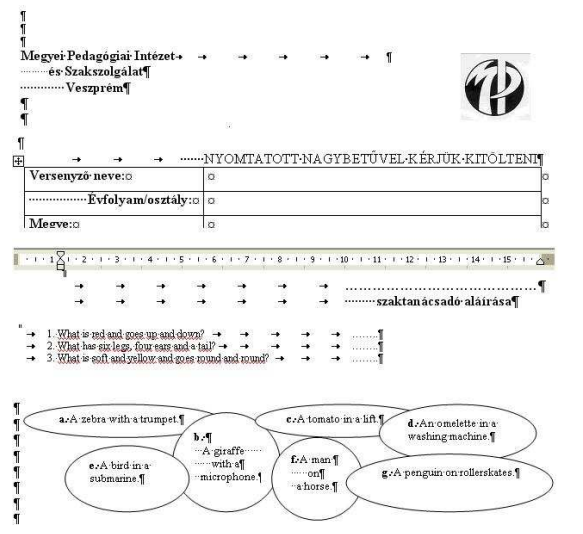

(b)

Figure 5. Examples are from two texts in connection with education. In 5 (a) the examples are from a lecture notes, while the examples in 5 (b) are from a test of an English competition.

"Square", at the end of the lines the end-of-paragraph character is inserted, manual hyphenation is used, and finally the language of the text is set to Portuguese instead of Hungarian.

The examples in Figure 5(b) are from a test of an English competition. The mistakes are the same: default TABS and SPACES for everything, incorrect language, unnecessary indentation, wrong layout of the pictures, manual numbering.

\subsubsection{Applied Informatics competitions}

The listed examples of this chapter are even more disappointing than those encountered above, because they are from teachers of Informatics, from those who should teach word processing.

The example in Figure 6 is from a competition where the word processing ability of high school students was to be tested. The task was to change the margin - should be further in by $3 \mathrm{~cm}$ - for the poem at the end of the text ${ }^{3}$, on page 4 (4. oldal in Figure 6 [8]). The sample document for the task was given both in file (.pdf) and in printed form (Figure 6). If we compare the instruction and the sample we can see that there is a mismatch. Based on the given instruction

3 ... versrészlet ... margói $3 \mathrm{~cm}$-mel beljebb legyenek, ... (quotation from the original document, translated by Autor) 


$$
\text { "csernoch" — 2009/5/29 — 9:48 — page } 131 \text { — \#13 }
$$

the formating cannot be performed, because Word inserts a section break with a new page if we want new margins for the poem. There were students who stuck to the original task, but got a five-page-long document instead of the required four, while others overruled the task and applied left and right indents.

Az épületet a Dréher család a következổ években romantikus stílusban átépitette. A díszterem faburkolatot, a mennyezet kazettás kialakitást kapott. A Dréherek vendégeként György walesi herceg, a későbbi VI. György angol király is járt az épületben.

1945 után államositották a kastélyt és úttörötábort helyeztek el benne. Később a legendás Aranycsapat edzőtáborát, majd 1957-ben szociális otthont alakítottak ki falai között.

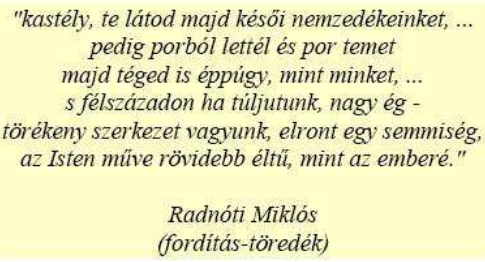

Figure 6. The example is from one of the tasks of the first round of the Informatics OKTV ${ }^{4} 2008$ [8], Applied Category. The task was to add to the poem - the yellow/gray spot on the bottom of the page on both sides an extra $3 \mathrm{~cm}$ margin.

Who was right? Let us now compare the correction guide of the task. One point is given if the document is on 4 pages, which is impossible because of the margins of the poem. One more point is given if the margins are set to the given values. There is no way for the students to gain both points. If the margins are set correctly, the first point is lost, if the document is four-page-long the second point is lost [9].

In the academic year of 1996-1997 I launched a survey to test the word processing ability of students. It was clear from the data of the survey that students had serious problems with distinguishing margins and indentations [17]. After

${ }^{4}$ OKTV, Országos Középiskolai Tanulmányi Verseny (Nation Wide Academic Competition for High Schools) 


$$
\text { "csernoch" — 2009/5/29 — 9:48 — page } 132 \text { — \#14 }
$$

encountering this example at the applied competition - more than ten years after the survey - it is obvious that even teachers of Informatics have no clear understanding of the two concepts.

After examining the word processing style of the correction guide of the same competition (Figures $7(\mathrm{a})-7(\mathrm{~d}))$ it is no wonder that this mistake could have occurred. These examples present the already familiar typical mistakes: manual numbering, positioning with wrong positioned tabulators, SPACES for positioning, text on the margin.

Figures $7(\mathrm{e})-7(\mathrm{~g})$ are from other Applied Informatics competitions, and unfortunately, they carry the mistakes listed above. It is already sad that mistakes from the administration and from teachers with various subjects set bad examples to students. It is, however, unacceptable that teachers of Informatics, who teach this subject are not able to generate correctly formatted texts.

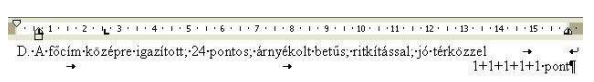

(a) $[9]$

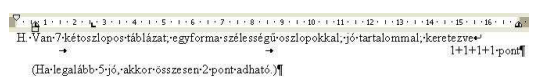

(b) $[11]$

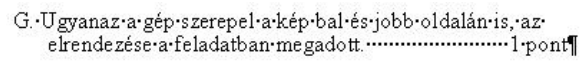

(c) $[13]$

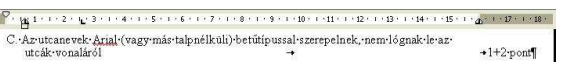

(d) $[12]$

\section{Programok:}

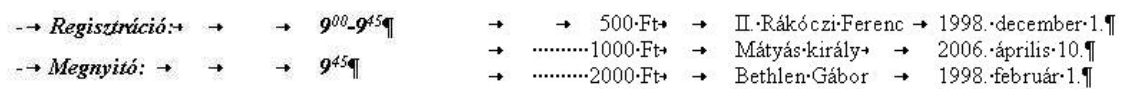

(e) $[16]$

(f)

c.) Az·egyén·kötelezettsége·adatainak·védelme.q

d.) Az:adatok·adatbázisainak·összekapcsolását-tiltja.q

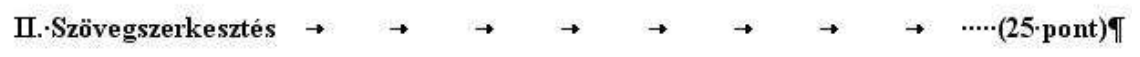

(g)

Figure 7. Selection from the correction guide for the competition of Informatics OKTV, Applied Category 7(a)-7(d). Pieces from the schedule for the finals of the Informatics $\mathrm{OÁTV}^{5} 7(\mathrm{e})$, and the test paper at an Applied Competition of Informatics of Hajdú-Bihar County (7(f)-

$7(\mathrm{~g}))$. 


$$
\text { "csernoch" — 2009/5/29 — 9:48 — page } 133 \text { — \#15 }
$$

\subsection{Is there any hope?}

In this final session I will present three examples from the works of students, who have passed the ECDL exam (Figure 8), and two examples from the Ministry of Education, one is from $2000^{6}$ (Figure 9(a)) and the other is from $2008^{7}$ (Figure 9(b)).

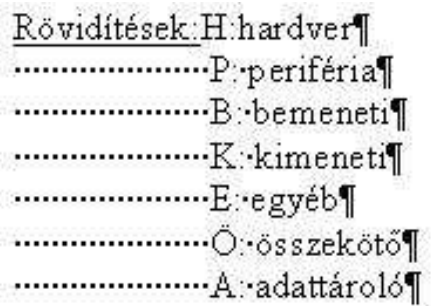

(a)

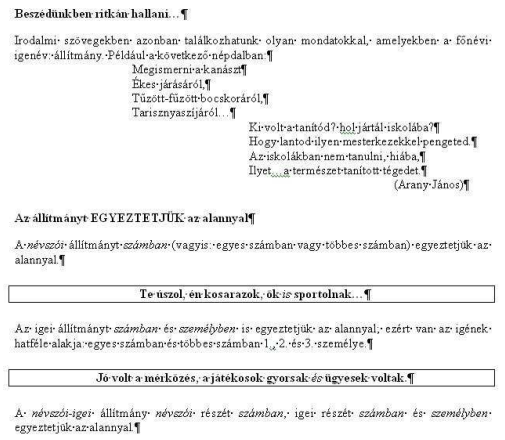

(c)

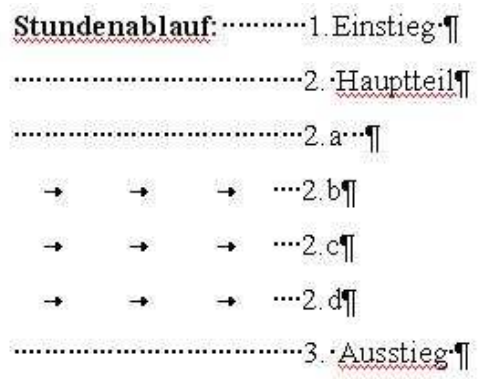

(b)

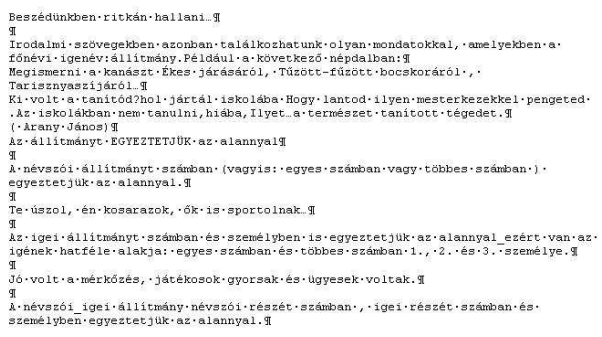

(d)

Figure 8. Examples from the works of students who have passed ECDL exam.

The examples in Figure 8(a) and 8(b) carry the same mistakes presented in the previous pictures, which means that a successful ECDL exam is no guarantee for a properly formatted text.

${ }^{5}$ OÁTV, Országos Általános Iskolai Tanulmányi Verseny (Nation Wide Academic Competition for Elementary and Junior High Schools)

${ }^{6} 28 / 2000$. (IX. 21.) OM

72/2008. (II.8.) OKM 
In Figure 8(c) an example text of a school assignment is given. The task was to open a text file, correct the mistakes of the text, repeat the formatting of the example, and save the file as a Word document. In Figure 8(d) the solution of a student, who passed ECDL exam is shown. The student was not able to create a Word document, was not able to use the SPACE and ENTER characters correctly, and all of his formatting were lost with the saving.

\begin{tabular}{|c|c|c|c|c|c|}
\hline -Tantárgyó & \multicolumn{5}{|c|}{ imok·évfolyamonkéntó } \\
\hline .0 & .90 & .100 & .110 &. .120 & \\
\hline -Magyar-nyelv-és-irodalomo & .1480 & .1480 & .1480 & .1280 & \\
\hline -Történelemo & .740 &. .740 &.$\cdot 1110$ & .960 & \\
\hline Emberismeret-és'etikaó & 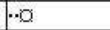 & $\cdot 0$ & .370 & 0 & \\
\hline -1.Idegen'nyelvo &. .1110 & .1110 & .1110 & .960 & \\
\hline -2.Idegen-nyelvio & $\cdot .1110$ &.$\cdot 1110$ &.$\cdot 1110$ & .960 & \\
\hline - Matematikao &. .1110 &.$\cdot 1110$ &. .1110 &. .1280 & \\
\hline - Informatika*o & .740 & $\because Q$ & $\because 0$ & 0 & \\
\hline - Bevezetés-a.filozófiábao & .0 & .0 & .0 &. .320 & \\
\hline
\end{tabular}

(a)

\begin{tabular}{|c|c|c|c|c|}
\hline \multirow[t]{2}{*}{ Tantárgy $x$} & \multicolumn{4}{|c|}{ Éves'óraszámok'évfolyamonkéntón } \\
\hline & $9 a$ & $10 \alpha$ & $11 a$ & $12 \alpha$ \\
\hline Magyar nyelvés irodalomo & $148 \%$ & $148 \%$ & $148 \%$ & $128 \%$ \\
\hline Történelem : & 740 & 55,50 & $111 \%$ & $96 \%$ \\
\hline Emberismeret'és etikaca & $\alpha$ & a & 370 & a \\
\hline 1. Idegen nyelvo & $111 \%$ & $92,5 \%$ & $111 \%$ & $96 \%$ \\
\hline 2.Idegen nyelvox & 92,50 & $74 \%$ & $111 \%$ & $96 \%$ \\
\hline Matematikax & $111 \%$ & $111 \%$ & $111 \%$ & $128 \mathrm{~m}$ \\
\hline Informatikă̈ & 55,50 & $37 \infty$ & $55,5 \%$ & $48 \%$ \\
\hline Bevezetés's a fillozófíábaá & $\not$ & s & \% & $32 \%$ \\
\hline
\end{tabular}

(b)

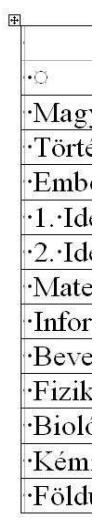

(c)

Figure 9. Examples are from the Ministry of Education, part of the National Curriculum. The difference between the two examples - 9(a) and $9(\mathrm{~b})$ - is that 9(a) was issued in 2000 while 9(b) is from 2008. Example 9(c) is enlarged from 9(a), to show that on the left there is an unnecessary empty column.

The examples in Figure 8 suggest that studying word processing in the educational system and then passing an exam does not have much influence on the students, which is disappointing to the extreme. However, seeing the documents of the Ministry of Education there is some hope. In the past seven years their 


$$
\text { "csernoch" — 2009/5/29 — 9:48 — page } 135 \text { — \#17 }
$$

table has developed a lot. It still carries some mistakes, but the extra, empty column on the left side has disappeared (enlarged in Figure 8(c)), they are able to merge cells, and the SPACE characters have also disappeared from the cells, which were originally used to centralize the numbers. I really hope that for the next curriculum they learn both the vertical and horizontal alignments, and that numbers should be aligned by decimal tab stops. The question is whether the increase in the number of the classes of Informatics by itself (compare Figures 9(a) and $9(\mathrm{~b}))$ is a guarantee for a much better education or not?

\section{Conclusions}

Experience shows that to find a properly formatted Word document is quite challenging. Most of the documents carry fundamental mistakes, starting with the incorrect layout of the text, followed by incorrect formats. To find reasons for this large-scale underperformance I checked the works of professionals, who work in administration, the works of teachers, the works of those who passed ECDL exam, and the works of teachers of Informatics. Unfortunately, these works were found to be no better than the works of amateurs. What explanations can be found for this ignorance?

First I found that there are no clear guidelines for what is a properly formatted text. Without such definition(s) it is almost impossible to declare that there are texts, which are correctly formatted, while others are not. To overcome this problem first the missing guidelines have to be set.

The guidelines which fulfill the concept of the properly formatted text are summarized in three maxims. These maxims rule out the incorrect uses of the SPACE and ENTER characters for the layout of the document, support formats which exclusively allow intentional corrections, and rule out improper formats.

These maxims first should serve as general rules for the teachers of Informatics, because until they are not familiar with the basic rules there is no chance for their students to perform better.

The answer to the question whether the increase in the number of the classes of Informatics by itself is a guarantee for a much better education or not, is clearly no. Until the teachers of Informatics are not qualified, the professionals will hand out texts that carry bad examples. Until these bad examples are circulating there is nothing for the students to follow. Until there is nothing good to follow there is little hope. Only, if we are able to change the attitude of the teachers of 


$$
\text { "csernoch" — 2009/5/29 — 9:48 — page } 136 \text { — \#18 }
$$

Informatics towards the properly formatted text, give them guidelines to follow, can these ideas spread, and then there is hope.

\section{References}

[1] A Beginner's Guide to Word Processing Using Microsoft Word, http://www. compusmart.ab.ca/alummis/beginnerword/.

[2] ECDLweb, Szövegbevitel, törlés, javtás, http://ecdlweb.uw.hu/m3-04.html.

[3] ECDLweb, Szövegfeldolgozási, szövegszerkesztési alapelvek, http://ecdlweb.uw.hu/m3-02.html.

[4] Szövegszerkesztés Worddel, http://www.lauder.hu/ attila/tan/alk/szovszerk/szovszerkw/szovszerkw.htm.

[5] What is word processing? - A Word Definition From the Webopedia Computer Dictionary, http://www.webopedia.com/TERM/W/word_processing.html.

[6] Atommag- és részecskefizika, http://falcon.phys.unideb.hu/kisfiz/Raics/F1404/.

[7] Index of /vmpisz/fix/versenyek, http://www.veszprem-ped.sulinet.hu/vmpisz/fix/versenyek/orsz_angol_2002_2003_2f .zip.

[8] NJSzT - Nemes Tihamér Országos Középiskolai Alkalmazói Tanulmányi Verseny 2007/2008 1. forduló OKTV alkalmazás kategóriája (11-12. osztály), http://tehetseg.inf.elte.hu/nemesa/2008/nt08-1f4.doc.

[9] NJSzT - Nemes Tihamér Országos Középiskolai Alkalmazói Tanulmányi Verseny 2007/2008 1. forduló OKTV alkalmazás kategóriája (11-12. osztály), http://tehetseg.inf.elte.hu/nemesa/2008/nt08-1m4.doc.

[10] NJSzT - Nemes Tihamér Országos Középiskolai Alkalmazói Tanulmányi Verseny 2005/2006 2. forduló Nemes Tihamér OKATV (9-10. osztály), http://tehetseg.inf.elte.hu/nemesa/2006/Nt06-2m5.doc.

[11] NJSzT - Nemes Tihamér Országos Középiskolai Alkalmazói Tanulmányi Verseny 2005/2006 2. forduló Nemes Tihamér OKATV (9-10. osztály), http://tehetseg.inf.elte.hu/nemesa/2006/Nt06-2m5.doc.

[12] NJSzT - Nemes Tihamér Országos Középiskolai Alkalmazói Tanulmányi Verseny 2005/2006 1. forduló Nemes Tihamér OKATV (9-10. osztály), http://tehetseg.inf.elte.hu/nemesa/2007/nt07-1m5.doc.

[13] NJSzT - Nemes Tihamér Országos Középiskolai Alkalmazói Tanulmányi Verseny 2005/2006 1. forduló Nemes Tihamér OKATV (9-10. osztály), http://tehetseg.inf.elte.hu/nemesa/2006/Nt06-1m5.doc.

[14] 28/2000. (IX. 21.) OM rendelet, http://www.okm.gov.hu/letolt/kozokt/torvenytar/2000_280M.doc.

[15] Kerettanterv a gimnáziumok számára, http://www.okm.gov.hu/letolt/kozokt/kerettanterv/kerettanterv_gimnazium_080328. doc.

[16] László Kozma, IV. Országos Informatika Alkalmazói Tanulmányi Verseny, http://www.isze.hu/download/453. 


$$
\text { "csernoch" — 2009/5/29 — 9:48 — page } 137 \text { — \#19 }
$$

[17] M. Csernoch, Methodological Questions of Teaching Word Processing, 3rd International Conference on Applied Informatics, Eger-Noszvaj, 1997, 375-382.

[18] L. Csernoch and L-né Csernoch, Word 6.0 gyakorlatok I., Nemzeti Tankönyvkiadó, Budapest, 1998a.

[19] L. Csernoch and L-né Csernoch, Word 6.0 gyakorlatok II., Nemzeti Tankönyvkiadó, Budapest, 1998b.

[20] F. Devecz, K. Jónás, T. Juhász, R. Kévés, Z. Reményi, G. Siegler and B. Takács, Irány az ECDL! a középszintü érettségi, Nemzeti Tankönyvkiadó, Budapest, 2004.

[21] Cs. Kiss and A. Krnács, Szövegszerkesztési ismeretek, Müszaki Könyvkiadó, Budapest, 2001.

[22] Topsec Informatikai és Oktatási Kft., Szövegszerkesztés, Microsoft Word XP. Informatikai és Hrközlési Minisztérium, Budapest, 2004.

MÁRIA CSERNOCH

UNIVERSITY OF DEBRECEN

KOSSUTH L. TEACHER TRAINING HIGH SCHOOL

H-4029 DEBRECEN, CSENGÖ STR. 4.

HUNGARY

E-mail: mariacsernoch@hotmail.com

(Received May, 2008) 